\title{
The $\beta$-carotene-rich alga Dunaliella bardawil as a source of retinol in a rat diet
}

\author{
BY A. BEN-AMOTZ \\ Israel Oceanographic and Limnological Research, Tel-Shikmona, PO Box 8030, Haifa \\ 31080, Israel \\ AND S. MOKADY \\ Department of Food Engineering and Biotechnology, Technion, Haifa 32000, Israel \\ AND M. AVRON \\ Biochemistry Department, The Weizmann Institute of Science, Rehovot 76100, Israel
}

(Received 9 February 1987 - Accepted 22 December 1987)

\begin{abstract}
1. Dunaliella bardawil, a $\beta$-carotene-accumulating alga, has been tested as a source of retinol and $\beta$-carotene in a diet given to rats. The $\beta$-carotene in this alga is composed of about equal amounts of the 9-cis and all-trans isomers. Male weanling rats were fed on a retinol-deficient diet for $60 \mathrm{~d}$. Thereafter, the rats were divided into groups and fed on a diet deficient in retinol or supplemented with retinol, synthetic $\beta$-carotene, dry alga or an algal oil-extract. Following further growth for $7 \mathrm{~d}$, samples were taken for liver analyses of retinol, retinol isomers and $\beta$-carotene.

2. Liver analyses revealed a comparable content of retinol and normal conversion rates in the rats grown on the diets supplemented with synthetic or natural $\beta$-carotene. Rats fed on the alga and the algal-oil-supplemented diets accumulated 9 -cis retinol in addition to the all-trans isomer. Rats fed on synthetic $\beta$-carotene, alga and algal oil had a liver retinol: $\beta$-carotene value of about $3: 1$.

3. These studies demonstrate the possibility of using dried $D$. bardawil or an oil extract of the alga as a dietary natural $\beta$-carotene supplement which satisfies the total requirement of retinol in rats.

4. Rats fed on alga or on algal oil, accumulated in the liver 9-cis $\beta$-carotene and all-trans $\beta$-carotene in a ratio similar to that present in the alga.
\end{abstract}

The halotolerant alga Dunaliella bardawil (Ben-Amotz \& Avron, 1981, 1983; Ben-Amotz, $1986)$ possesses the unique ability to accumulate a very high content of $\beta$-carotene. The amount of $\beta$-carotene in $D$. bardawil can be manipulated by appropriate growth conditions to vary from about $3 \mathrm{~g} / \mathrm{kg}$ as commonly found in other green algae and plants, to over $100 \mathrm{~g} / \mathrm{kg}$. Furthermore, the fact that this alga lacks an indigestible cellulotic cell wall, in contrast to other green algae and higher plants, has made it a favourite organism for study as a health food rich in $\beta$-carotene and as a source of natural food colouring (Klausner, 1986).

In a recent paper (Ben-Amotz et al. 1986), we reported that dry D. bardawil rich in $\beta$-carotene successfully replaced synthetic retinol in a chick diet.

This alga and the closely related species $D$. salina Teod. have been grown on a commercial scale in outdoor ponds for the last few years for the production of natural $\beta$-carotene and an algal meal rich in $\beta$-carotene (Ben-Amotz \& Avron, 1983).

The $\beta$-carotene found in $D$. bardawil (Ben-Amotz et al. 1982) and in many fruits and vegetables contains about $50 \%$ all-trans $\beta$-carotene with the rest composed mostly of 9-cis $\beta$-carotene and minor amounts of a few other $\beta$-carotene isomers. All-trans $\beta$-carotene is classically considered to have a higher retinol biopotency than the 9-cis isomer (Deuel et al. 1944). The question of the biopotency of 9-cis $\beta$-carotene was repeatedly raised in the last decade, but attempts to resolve the issue were hampered by the lack of a readily available source of this isomer. $D$. bardawil provides an excellent source of natural 
$\beta$-carotene, accumulated intracellularly in the form of lipoidal globules, containing approximately equivalent amounts of 9-cis and all-trans $\beta$-carotene (Ben-Amotz et al. 1982). Jensen et al. (1987) have recently reported on the utilization of Dunaliella in a human diet and on the conversion of the algal 9-cis $\beta$-carotene to all-trans $\beta$-carotene in human serum.

In the present paper we report that feeding $D$. bardawil rich in $\beta$-carotene to rats supplies retinol, 9-cis retinol, $\beta$-carotene and 9-cis $\beta$-carotene to their livers.

\section{MATERIALS AND METHODS \\ Alga}

$D$. bardawil was grown in outdoor culture under natural illumination as previously described (Ben-Amotz et al. 1982). Alga was collected by centrifugation and dried by lyophilization. The dried alga contained $(\mathrm{g} / \mathrm{kg})$ about $50 \beta$-carotene and an ash content of 300 , mostly sodium chloride.

\section{Provatene $^{\circledR}$}

Provatene is a commercial maize-oil extract of Dunaliella containing about $15 \mathrm{~g}$ $\beta$-carotene/kg (Microbio Resources Inc., San Diego, CA, USA).

\section{Animals and diets}

Male weanling rats of the Charles River CD strain were fed ad lib. on a retinol-deficient diet containing $100 \mathrm{~g}$ protein (derived from vitamin-free casein) $/ \mathrm{kg}$. The diet was designed according to the Association of Official Analytical Chemists (1984) but was lacking retinol. At the end of a period of $60 \mathrm{~d}$, the retinol content of the livers of the depleted rats was 4-5 $\mu \mathrm{g}$. These rats were divided into groups of six, housed in individual cages and fed on the retinol-deficient diet supplemented with: treatment 1 , retinol at $7.5 \mathrm{mg} / \mathrm{kg}$ diet; treatments $2-4$, all-trans $\beta$-carotene at 12,29 or $48 \mathrm{mg} / \mathrm{kg}$ diet; treatments $5-7, \beta$-carotene contributed by lyophilized $D$. bardawil at 29,58 or $112 \mathrm{mg} \beta$-carotene $/ \mathrm{kg}$ diet; treatment 8 , Provatene providing $16 \mathrm{mg} \beta$-carotene $/ \mathrm{kg}$ diet; treatment 9 , no supplementation.

\section{Assays}

At the end of a $7 \mathrm{~d}$ feeding period, the rats were killed, and their livers removed, weighed, and stored at $-18^{\circ}$. Retinol in the livers were extracted according to Ames et al. (1954) and determined spectrophotometrically with trifluoroacetic acid by the method of Dugan et al. (1964). Retinol recovery in the livers was calculated according to Sweeny \& Marsh (1974).

\section{High-performance liquid chromatography (HPLC)}

Extraction. Samples of $D$. bardawil were centrifuged shortly before the analysis and the algal pellet was extracted with acetone. Pigments were transferred to light petroleum (b.p. $40-60^{\circ}$ ) with a small amount of water, and after phase separation the upper phase containing the pigments was evaporated to dryness under nitrogen. The dry material was redissolved in a small amount of methylene chloride and the pigments determined by HPLC. The time period of pigment extraction and purification from fresh alga was not more than $15 \mathrm{~min}$. Synthetic $\beta$-carotene was dissolved in methylene chloride before chromatography.

Retinol and $\beta$-carotene in the liver were extracted as described by Zile et al. (1977) with three repeated extractions of water-ethanol-light petroleum (b.p. 40-60 $)(1: 1 \cdot 5: 5$, by vol.) under nitrogen. After phase separation, the upper phase was divided into two equal samples and evaporated to dryness. One was dissolved in a minimal volume of methanol-water $(9: 1, \mathrm{v} / \mathrm{v})$ for retinol determination by HPLC (De Leenheer et al. 1979; 
Villard \& Bates, 1986), and the other was dissolved in a small volume of methylene chloride for determination of $\beta$-carotene and other carotenoids by HPLC.

Columns and solvents. Two different columns were used for the HPLC analysis. For total pigment and $\beta$-carotene isomer analysis, we used a stainless-steel column of $250 \mathrm{~mm} \times 4.6$ $\mathrm{mm}$ i.d. packed with $\mathrm{C} 18$ reversed-phase material of $5 \mu \mathrm{m}$ particle size (Vydac 201 TP54, The Separation Group, P.O. Box 867, Hesperia, CA, USA). The elution on the Vydac column was performed with an isocratic solvent of methanol acetonitrile $(9: 1, v / v)$ at 1 $\mathrm{ml} / \mathrm{min}$. This column was found to provide excellent separation of all-trans and 9 -cis $\beta$ carotene as well as the liver-extracted retinyl esters (retinyl palmitate, retinyl stereate, etc). The Vydac column had to be washed every few days with methanol-acetonitrile-methylene chloride $(8: 1: 1$, by vol.).

For retinol and retinol isomer analysis, a stainless-steel column of $150 \mathrm{~mm} \times 4.6 \mathrm{~mm}$ i.d. was used packed with $\mathrm{C} 18$ reversed-phase material of $5 \mu \mathrm{m}$ particle size (Novapak Waters). The elution of retinol and its 9 -cis isomer was conducted with an isocratic solvent, methanol-water $(9: 1, \mathrm{v} / \mathrm{v})$, at $1 \mathrm{ml} / \mathrm{min}$.

HPLC equipment. HPLC of the pigments, retinol and retinyl esters was performed with a Waters HPLC system equipped with a Waters 510 pump, 501 pump and Waters U6K injector. Detection was by a Waters 490 Programmable Multiwavelength Detector adjusted to $330 \mathrm{~nm}$ for detection of retinol and retinyl esters, $436 \mathrm{~nm}$ for chlorophylls, and $450 \mathrm{~nm}$ for carotenoids. The multiwavelength detector was connected through a System Interface Module to a four channel Waters 840 Data and Chromatography Control Station on a Digital 350 Professional Computer. The fourth available channel was used for peak identity verification with fluorescence detection of chlorophyll or retinol by a Waters $420 \mathrm{AC}$ Fluorescence Detector equipped with either Waters 78224 excitation filter of $338 \mathrm{~nm}$ and Waters 78229 cut-off emission filter of $400 \mathrm{~nm}$ for retinol determination, or Waters 78227 excitation filter of $450 \mathrm{~nm}$ and Waters 78233 cut-off emission filter of $530 \mathrm{~nm}$ for chlorophyll determination. The fluorimeter was used with S5 or S20 photomultipliers for general fluorescence or red fluorescence of chlorophyll respectively.

All-trans retinol (synthetic) was obtained from Sigma Chemical Co., St Louis, MO, USA and all-trans $\beta$-carotene and 9-cis (synthetic) were obtained from Hoffmann La Roche, Basel, Switzerland.

The statistical significance of all treatments was determined by $t$ tests.

RESULTS

Analysis of the diets by HPLC

The dry powder of the alga $D$. bardawil, which was used in the dietary experiments, contained about $50 \mathrm{~g} \beta$-carotene $/ \mathrm{kg}$ in addition to the other common higher plant pigments. Analysis of the algal pigments by HPLC showed that the $\beta$-carotene was composed of $(\mathrm{mg} / \mathrm{g})$ approximately 450 9-cis $\beta$-carotene and 550 all-trans isomer. Synthetic $\beta$-carotene consisted mostly of all-trans $\beta$-carotene and contained no 9 -cis isomer (Fig. 1). The algal-oil extract (Provatene) contained about $15 \mathrm{~g} \beta$-carotene $/ \mathrm{kg}$ with a similar 9-cis:alltrans value to that in the algae (not shown).

\section{Dietary studies}

The utilization of $D$. bardawil $\beta$-carotene, synthetic $\beta$-carotene and a standard diet containing retinol was evaluated in rats by measurement of the retinol biopotency. The spectrophotometric assay of liver retinol (Fig. 2), including retinol isomers and retinyl esters, showed the presence of retinol in all rats except for the retinol-deficient rats. The percentage conversion of $\beta$-carotene to retinol was similar in all the treatments, except for the highest dietary $\beta$-carotene level (Table 1). 


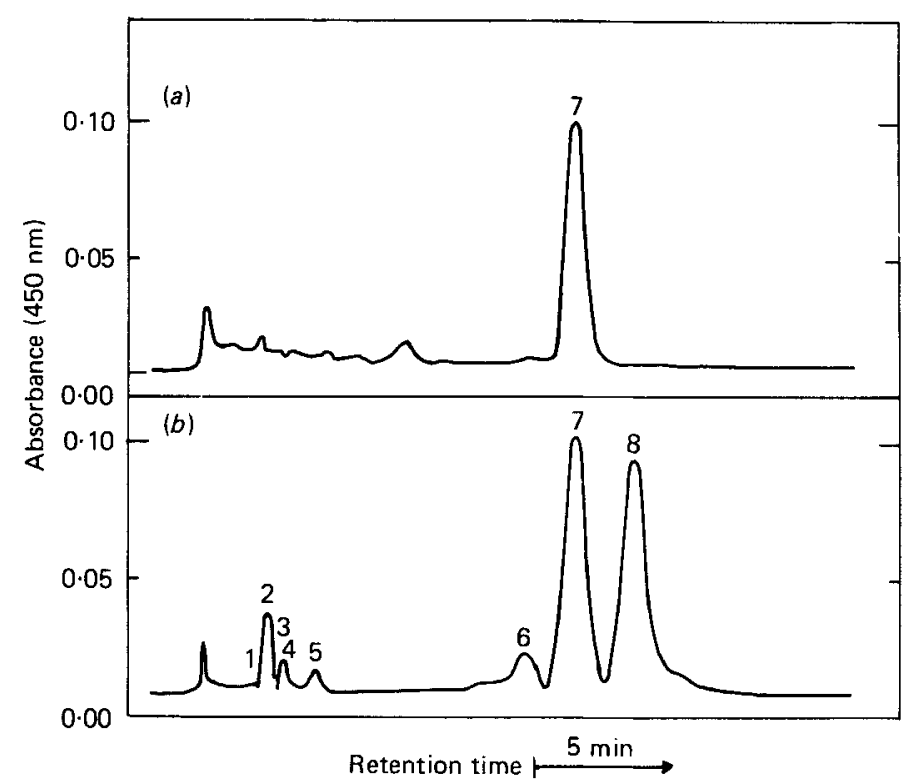

Fig. 1. Carotene analysis by high-performance liquid chromatography of $(a)$ synthetic $\beta$-carotene and $(b)$ an extract of Dunaliella bardawil. 1, Chlorophyll $b ; 2$, lutein; 3, unidentified; 4, zeaxanthin; 5 , chlorophyll $a ; 6, \alpha$-carotene; 7, all-trans $\beta$-carotene; 8, 9-cis $\beta$-carotene. Chromatographic conditions: column, Vydac, C18, 201TP54, $5 \mu \mathrm{m}$; eluant, methanol-acetonitrile $(9: 1, \mathrm{v} / \mathrm{v})$; flow rate, $1 \mathrm{ml} / \mathrm{min}$; detection, $450 \mathrm{~nm}$.

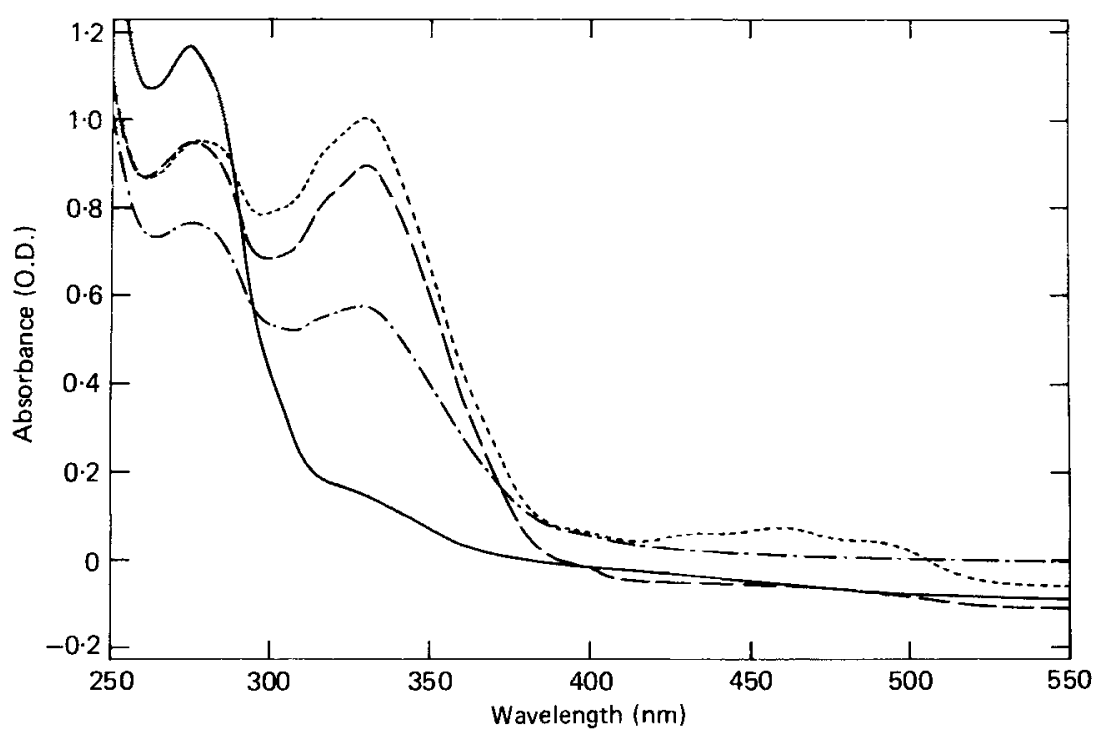

Fig. 2. Absorption spectra of liver extracts of rats fed on a retinol-deficient diet with different supplements. $(-)$, Retinol-deficient diet; $(-.-)$, retinol-deficient diet supplemented with retinol; $(---)$, retinoldeficient diet supplemented with $\beta$-carotene; ( - -), retinol-deficient diet supplemented with Dunaliella bardawil. For details of dietary treatments, see p. 444. 
Table 1. Synthetic $\beta$-carotene and Dunaliella bardawil as a retinol source for rats

(Retinol-deficient rats were fed on the specified diet for $7 \mathrm{~d}$; for details, see p. 444)

\begin{tabular}{|c|c|c|c|c|c|}
\hline \multirow[b]{2}{*}{ Diet supplementation } & \multirow{2}{*}{$\begin{array}{c}\text { Dietary } \\
\beta \text {-carotene } \\
(\mathrm{mg} / \mathrm{kg} \text { diet })\end{array}$} & \multirow{2}{*}{$\begin{array}{c}\beta \text {-Carotene } \\
\text { consumed } \\
(\mu \mathrm{g})\end{array}$} & \multicolumn{3}{|c|}{$\begin{array}{c}\text { Recovered as retinol (and retinyl } \\
\text { ester) in liver }\end{array}$} \\
\hline & & & $\mu \mathrm{g}$ & Mean ${ }^{\dagger}$ & SE \\
\hline None & - & - & 1.5 & - & \\
\hline Retinol $(7.5 \mathrm{mg} / \mathrm{kg}$ diet $)$ & - & - & 330 & -- & \\
\hline$\beta$-carotene & $\begin{array}{l}12 \\
29 \\
48\end{array}$ & $\begin{array}{l}1.080 \\
2030 \\
4440\end{array}$ & $\begin{array}{r}69 \\
140 \\
300\end{array}$ & $\begin{array}{l}6 \cdot 4 \\
6 \cdot 9 \\
6 \cdot 7\end{array}$ & $\begin{array}{l}0 \cdot 8 \\
1 \cdot 0 \\
1 \cdot 0\end{array}$ \\
\hline D. bardawil & $\begin{array}{r}29 \\
58 \\
112\end{array}$ & $\begin{array}{r}2840 \\
5490 \\
10000\end{array}$ & $\begin{array}{l}160 \\
322 \\
415\end{array}$ & $\begin{array}{l}5 \cdot 6 \\
5 \cdot 9 \\
4 \cdot 1^{*}\end{array}$ & $\begin{array}{l}0 \cdot 6 \\
0 \cdot 6 \\
0 \cdot 5\end{array}$ \\
\hline Provatene ${ }^{8} \ddagger$ & 16 & 1410 & 92 & $6 \cdot 5$ & $0 \cdot 8$ \\
\hline
\end{tabular}

* Mean value was significantly different from the other values $(P<0.01)$.

$\dagger$ Mean percentage values for six determinations.

$\ddagger$ Commercial maize-oil extract of Dunaliella (Microbio Resources Inc., San Diego, CA, USA).

Table 2. Retinol and $\beta$-carotene content of livers of rats fed on diets supplemented with retinol, $\beta$-carotene, Dunaliella bardawil or Provatene ${ }^{\otimes}$

(Mean values with their standard errors for three determinations)

\begin{tabular}{|c|c|c|c|c|}
\hline \multirow[b]{3}{*}{ Diet supplementation } & \multicolumn{4}{|c|}{$\begin{array}{c}\text { Content in the liver } \\
(\mu \mathrm{g} / \mathrm{g} \text { wet wt })\end{array}$} \\
\hline & \multicolumn{2}{|c|}{$\begin{array}{l}\text { Retinol (and } \\
\text { retinyl esters) }\end{array}$} & \multicolumn{2}{|c|}{$\beta$-carotene } \\
\hline & Mean & SE & Mean & $\mathbf{S E}$ \\
\hline None & $<1 \cdot 0$ & & $<0.5$ & \\
\hline Retinol ( $7.5 \mathrm{mg} / \mathrm{kg}$ diet $)$ & 106 & 5 & $1 \cdot 0$ & $0 \cdot 1$ \\
\hline$\beta$-Carotene $(29 \mathrm{mg} / \mathrm{kg}$ diet $)$ & 67 & 3 & $22 \cdot 1$ & $1 \cdot 1$ \\
\hline $\begin{array}{l}\text { D. bardawil } \\
\text { ( } 29 \mathrm{mg} \beta \text {-carotene } / \mathrm{kg} \text { diet) }\end{array}$ & 60 & 3 & $27 \cdot 5$ & $1 \cdot 8$ \\
\hline $\begin{array}{l}\text { Provatene } \\
\text { (16 } \mathrm{mg} \beta \text {-carotene } / \mathrm{kg} \text { diet })\end{array}$ & 36 & 3 & $12 \cdot 8$ & $0 \cdot 9$ \\
\hline
\end{tabular}

* Commercial maize-oil extract of Dunaliella (Microbio Resources Inc., San Diego, CA, USA).

Analysis of the liver extract by HPLC

The liver extracts were analysed by HPLC for retinol and $\beta$-carotene (Table 2). All extracts, except those of the retinol-deficient rats, contained all-trans retinol. The liver extract of rats fed on a diet supplemented with $D$. bardawil (or Provatene, not shown) contained, in addition to the all-trans retinol, about $400 \mathrm{~g} \mathrm{9-cis} \mathrm{retinol} / \mathrm{kg}$ (Fig. 3). A similar analysis of the liver extracts for $\beta$-carotene and its isomers (Fig. 4) showed that both all-trans $\beta$ carotene and the 9-cis isomer were present in the liver of rats fed on $D$. bardawil (or Provatene, not shown), while the liver extracts of rats fed on synthetic $\beta$-carotene contained essentially only all-trans $\beta$-carotene. Peak no. 4 , which was not identified, was present in all groups while the unidentified peak no. 1 was present only in the alga-fed rats. 


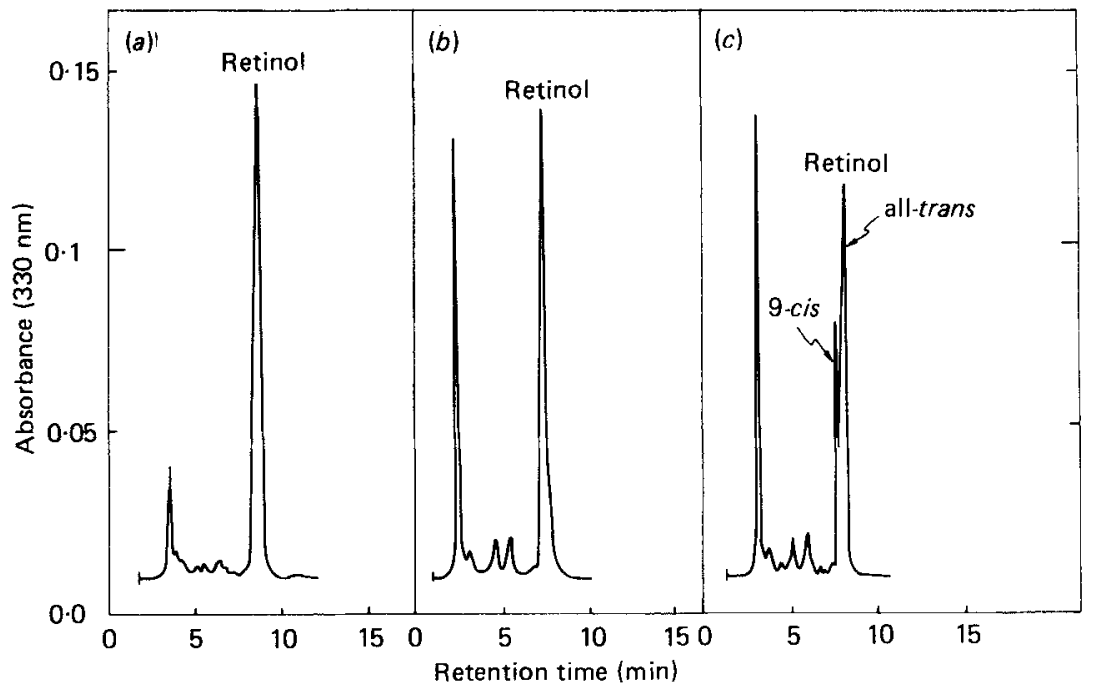

Fig. 3. Retinol analysis by high-performance liquid chromatography of liver extracts of rats fed on a retinol-deficient diet supplemented with $(a)$ retinol, $(b)$ synthetic $\beta$-carotene or (c) Dunaliella bardawil. Chromatographic conditions: column, NovaPak Cl8 (Waters), $5 \mu \mathrm{m}$; eluant, methanol-water $(9: 1$, $\mathrm{v} / \mathrm{v}$ ); flow rate, $1 \mathrm{ml} / \mathrm{min}$; detection, $330 \mathrm{~nm}$. Non-labelled peaks were not identified. For details of dietary treatments, see p. 444.

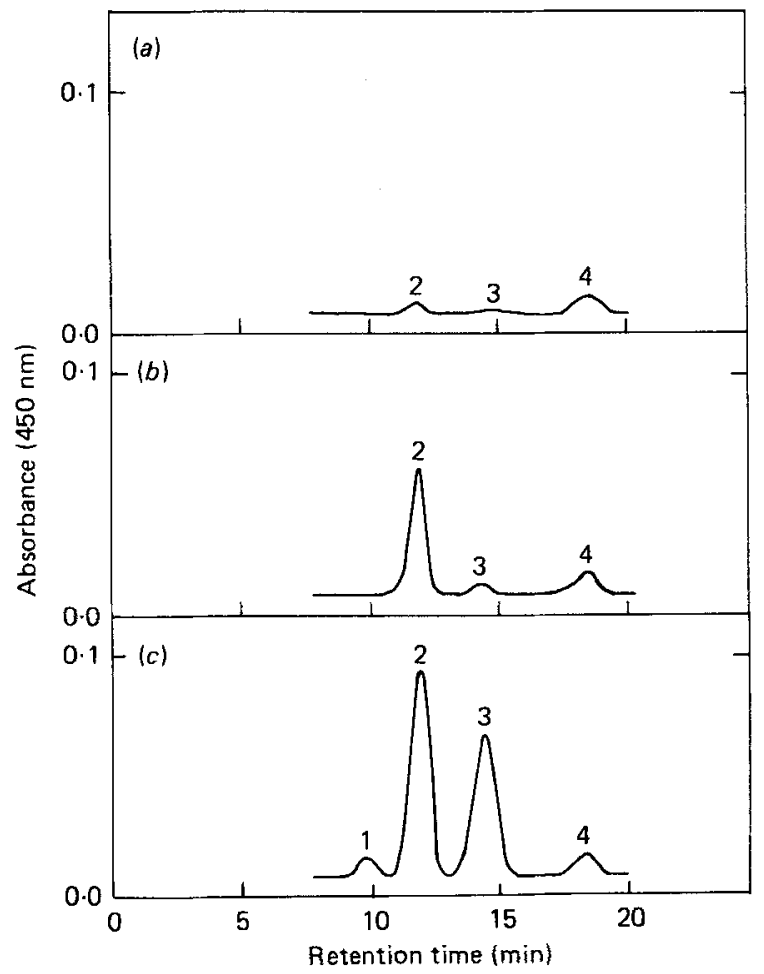

Fig. 4. Carotene analysis by high-performance liquid chromatography of liver extracts of rats fed on a retinol-deficient diet supplemented with $(a)$ retinol, $(b)$ synthetic $\beta$-carotene or $(c)$ Dunaliella bardawil. 1 , $\alpha$-Carotene; 2 , all-trans $\beta$-carotene; 3, 9-cis $\beta$-carotene; 4 , unidentified. Injections occurred at the point of $1 \mathrm{~min}$. Chromatographic conditions: column. Vydac, C18, 201TP54, $5 \mu \mathrm{m}$; eluant, methanol-acetonitrile $(9: 1, \mathrm{v} / \mathrm{v})$; flow rate, $1 \mathrm{ml} / \mathrm{min}$; detection, $450 \mathrm{~nm}$. For details of dietary treatments, see p. 444. 


\section{DISCUSSION}

$\beta$-carotene is an excellent source of retinol in most diets, including human diets (Bauernfeind et al. 1981). Nevertheless, algae have not been extensively studied as a source of retinol because of the relatively low content of $\beta$-carotene in most algae (around $2 \mathrm{~g} / \mathrm{kg}$ ). $D$. bardawil, and the closely related species $D$. salina Teod., when grown in mass culture (Ben-Amotz \& Avron, 1983; Klausner, 1986) contain at least $50 \mathrm{~g} \beta$-carotene $/ \mathrm{kg}$ dry weight. Since $D$. bardawil contains an approximately equivalent amount of all-trans $\beta$-carotene and its 9-cis isomer (Ben-Amotz et al. 1982), the inclusion of this alga in the diet also provides information on the utilization, absorption, storage and conversion of the isomer.

Jensen et al. (1987) have recently used an oil extract of $D$. salina Teod. in a study of $\beta$-carotene conversion in humans. Their study had to be restricted to serum analysis of normally fed subjects. Our study on rats (see also Deuel et al. 1944; Sweeny \& Marsh, 1974) allowed a detailed study of the liver content of $\beta$-carotene, retinol and their isomers. It is clear that the rat liver accumulated both $\beta$-carotene and its 9 -cis isomer in the same ratio as that present in the diet, and that the liver retinol comprised significant amounts of retinyl esters, retinol and 9-cis retinol (Pangala \& Lacroix, 1986). Our results do not support the earlier conclusion of Thompson et al. (1949) that the rat absorbs little carotene beyond the intestinal mucosa, but are in agreement with a more recent study which showed that the rat plasma $\beta$-carotene level increases with supplementation (Shapiro et al. 1984).

The bioconversion of the $\beta$-carotene of $D$. bardawil into retinol and retinyl esters in the liver of rats was similar to that of synthetic $\beta$-carotene, about $6 \%$. With higher supplementation of $D$. bardawil to the rat diet, the percentage conversion to retinol was significantly lower. This is in agreement with previous observations which showed that when $\beta$-carotene is fed at high levels, the relative efficiency of conversion to retinol and its tissue storage are reduced (Bauernfeind et al. 1981). The effect of the high supplementation with $D$. bardawil or synthetic $\beta$-carotene was also apparent in the colouration of the liver.

\section{REFERENCES}

Ames, S. R., Risley, H. A. \& Harris, P. L. (1954). Analytical Chemistry 26, 1378-1381.

Association of Official Analytical Chemists (1984). Official Methods of Analysis, 14th ed., pp. 877-878. Arlington, VA: Association of Official Analytical Chemists.

Bauernfeind, J. C., Adams, C. R. \& Marusich, W. L. (1981). In Carotenoids as Colorants and Vitamin A Precursors, pp. 564-743 [J. C. Bauernfeind, editor]. New York: Academic Press.

Ben-Amotz, A. (1986). Beihefte zur Nova Hedwigia 83, 132-135.

Ben-Amotz, A. \& Avron, M. (1981). Trends in Biochemical Sciences 6, 297-299.

Ben-Amotz, A. \& Avron, M. (1983). Annual Review of Microbiology 37, 95-119.

Ben-Amotz, A., Edelstein, S. \& Avron, M. (1986). British Poultry Science 27, 613-619.

Ben-Amotz, A., Katz, A. \& Avron, M. (1982). Journal of Phycology 18, 529-537.

De Leenheer, A. P., De Bevere, J. O. R. C., De Ruyter, M. G. M. \& Claeyer, A. E. (1979). Journal of Chromatography 162, 408-413.

Deuel, H. J., Johnston, C., Sumner, E., Polgar, A. \& Zechmeister, L. (1944). Archives in Biochemistry 5, $107-112$.

Dugan, R. E., Frigerio, N. A. \& Siebert, J. M. (1964). Analytical Chemistry 36, 114-118.

Jensen, C. D., Howes, T. W., Spiller, G. A., Pattison, T. S., Wittam, J. H. \& Scala, J. (1987). Nutrition Reports International 35, 413-422.

Klausner, A. (1986). Biotechnology 4, 947-953.

Pangala, V. B. \& Lacroix, A. (1986). Methods in Enzymology 123, 75-85.

Shapiro, S. S., Mott, D. J. \& Machlin, L. J. (1984). Journal of Nutrition 114, 1927-1930.

Sweeny, J. P. \& Marsh, A. C. (1974). Journal of Nutrition 104, 1115-1120.

Thompson, S. Y., Ganguly, J. \& Kon, S. K. (1949). British Journal of Nutrition 3, 50-78.

Villard, L. \& Bates, C. J. (1986). British Journal of Nutrition 56, 115-122.

Zile, M., Bunge, E. C. \& Deluca, H. F. (1977). Journal of Nutrition 107, 552-560. 